\title{
Removal of Platinum and Palladium from Wastewater by Means of Biosorption on Fungi Aspergillus sp. and Yeast Saccharomyces sp.
}

\author{
Beata Godlewska-Żyłkiewicz *(D), Sylwia Sawicka and Joanna Karpińska \\ Institute of Chemistry, University of Bialystok, K. Ciołkowskiego 1K, 15-245 Białystok, Poland \\ * Correspondence: bgodlew@uwb.edu.pl
}

Received: 5 June 2019; Accepted: 14 July 2019; Published: 23 July 2019

check for updates

\begin{abstract}
The emission of platinum group metals from different sources has caused elevated concentrations of platinum and palladium in samples of airborne particulate matter, soil, surface waters and sewage sludge. The ability of biomass of Aspergillus sp. and yeast Saccharomyces sp. for removal of $\mathrm{Pt}(\mathrm{IV})$ and $\mathrm{Pd}(\mathrm{II})$ from environmental samples was studied in this work. The $\mathrm{pH}$ of the solution, the mass of biosorbent, and contact time were optimized. The Langmuir and Freundlich adsorption isotherms and kinetic results were used for interpretation of the process equilibrium of $\mathrm{Pt}(\mathrm{IV})$ and $\mathrm{Pd}(\mathrm{II})$ on both microorganisms. The maximal efficiency of retention of $\mathrm{Pt}(\mathrm{IV})$ on yeast and fungi was obtained at acidic solutions ( $\mathrm{pH} 2.0$ for Pt(IV) and $\mathrm{pH} 2.5-3.5$ for $\mathrm{Pd}(\mathrm{II})$ ). The equilibrium of the biosorption process was attained within $45 \mathrm{~min}$. The best interpretation for the experimental data was given by the Langmuir isotherm. Kinetics of the $\mathrm{Pt}$ and $\mathrm{Pd}$ adsorption process suit well the pseudo-second-order kinetics model. Fungi Aspergillus sp. shows higher adsorption capacity for both metals than yeast Saccharomyces sp. The maximum adsorption capacity of fungi was $5.49 \mathrm{mg} \mathrm{g}^{-1}$ for Pt(IV) and $4.28 \mathrm{mg} \mathrm{g}^{-1}$ for Pd(II). The fungi possess the ability for efficient removal of studied ions from different wastewater samples (sewage and road run-off water). It was also demonstrated, that quantitative recovery of Pd from industrial wastes could be obtained by biosorption using Aspergillus sp.
\end{abstract}

Keywords: biosorption; precious metals; selective sorbent; isotherm adsorption models; environmental samples; run-off water

\section{Introduction}

Platinum and palladium due to their corrosion resistance, alloying ability and unique catalytic properties are used in various chemical productions and metallurgy. The electrical conductivity and durability of these metals are exploited in electronic applications for the production of multi-layer ceramic (chip) capacitors, and plating connectors and lead frames. Components inside computers and mobile phones are linked by connectors plated with a conductive layer of precious metal [1]. The production of PC computers, mobile phones and entertainment devices generates electronic waste (e-waste) [2]. However, the most important application of $\mathrm{Pt}$ and $\mathrm{Pd}$ is connected with the production of three-way catalytic converters for car engines [3]. The emission of these metals into the environment is connected with the operation of vehicle catalysts and their recycling. Elevated concentrations of $\mathrm{Pt}$ and $\mathrm{Pd}$ have been found in samples of airborne particulate matter, road and tunnel dust, and soil close to the roads [4-6]. Discharges of anthropogenic contamination to surface waters include both atmospheric deposition and stormwater runoff. Analysis of sewage sludge, surface waters, and ditch sediments demonstrated that the anthropogenic activity has resulted in elevated concentrations of these elements in such samples [6-8]. Globally, Nuss and Blengini [9] have found that anthropogenic 
fluxes of $\mathrm{Pd}$ and $\mathrm{Pt}$ induced by the EU-28 countries might be greater than the respective global natural fluxes. Therefore, methods and processes for the removal of precious metals from waste have become necessary for the creation of the sustainable world [2]. To decrease the pollution with heavy metals, many processes like adsorption, precipitation, coagulation, ion-exchange, electro-dialysis have been developed [10]. One of the modern environmentally friendly technologies for the recovery of platinum group metals is biosorption [11].

A literature survey shows that microorganisms and native biomaterials, such as industrial and agricultural wastes and compounds derived from plant and animal tissues (e.g., lignin, tannin, chitin and chitosan), have been used as effective metal sorbents [11-15]. The majority of studies devoted to biosorption of $\mathrm{Pt}$ and $\mathrm{Pd}$ have been performed on biomass derived from plants and marine organisms [16-22] with various derivatives of chitosan preferred [16-18]. Very few microorganisms (some strains of bacteria, algae, fungi) [23-30] and Tobacco mosaic virus [13] have been used for this purpose. The recovery of platinum by a poly(ethylenimine) (PEI) modified biomass, prepared by attaching PEI onto the surface of inactive Escherichia coli biomass was reported by Won et al. [23]. This sorbent was tested for the removal of Pt from wastewater collected from an industrial laboratory. In the next paper Won et al. [24] used PEI-modified Corynebacterium glutamicum for recovery of Pd from the hydrochloric acid solution. Different species of Desulfovibrio, sulfate-reducing bacteria, have an ability to remove $\mathrm{Pd}(\mathrm{II})$ at $\mathrm{pH} 3$ with its further reduction to $\mathrm{Pd}(0)$. The potential of such bacteria was also shown for the recovery of $\mathrm{Pt}$ and $\mathrm{Pd}$ from spent automotive catalyst leachates using hydrogen as the reductant [25]. Turner et al. [28] studied the uptake of platinum group elements by marine macroalgae, Ulva lactuta in sea water. Algae Chlorella vulgaris immobilized on cellulose have been used for the selective separation of $\mathrm{Pt}$ and $\mathrm{Pd}$ from environmental matrices [29]. A sulfothermophilic red microalga, Galdieria sulphuraria, living in hot sulfur springs, was used for simultaneous removal of gold and palladium from model wastewater [30]. Competitive biosorption of $\mathrm{Pt}(\mathrm{IV})$ and $\mathrm{Pd}(\mathrm{II})$ by Escherichia coli [26] and Providencia vermicola [27] was studied in model solutions.

Saccharomyces sp. is a single-cell yeast being used for the biofuel, bakery and beverage industries or for the production of biotechnological products. Such biomass possesses an ability to accumulate a broad range of heavy metals under a wide range of external conditions [31]. Mack et al. [32] have studied a kinetic of the sorption of Pt by immobilized Saccharomyces cerevisiae under acidic conditions. Godlewska-Żyłkiewicz [33] observed the highest retention of platinum (62\%-65\%) and palladium $(95 \%)$ on free cells of baker's yeast at $\mathrm{pH}$ range from 1.6 to 2.2. A solid-phase extraction procedure using yeast $S$. cerevisiae immobilized in calcium alginate beads was proposed for the determination of $\mathrm{Pd}$ in road dust by electrothermal atomic absorption spectrometry (ETAAS) [34]. Yeast S. cerevisiae immobilized on a cellulosic resin was also used for selective on-line separation of Pt(IV) from river water prior to its chemiluminescent determination [35].

The fungal microorganisms are used extensively in a variety of large-scale industrial fermentation processes and production of gluconic acid, citric acid and many enzymes [36]. Waste biomass of free and immobilized cells of Aspergillus was used to remove heavy metal ions, such as cadmium, lead, chromium, iron and nickel from different matrices [37-39]. The first report on the bioaccumulation of platinum and other metals by fungi was published by Moore et al. [40]. The uptake efficiency of $\mathrm{Pt}$ equal to $85 \%$ at $\mathrm{pH} 2-3$ within $48 \mathrm{~h}$ was reported. It was also demonstrated that Aspergillus sp. immobilized on cellulose resin Cellex-T could be used as a selective sorbent for solid-phase extraction of $\mathrm{Pt}$ and $\mathrm{Pd}$ from the complex matrix of road dust [41].

In this work, the ability of biomass of Aspergillus sp. and yeast Saccharomyces sp. for biosorption of $\mathrm{Pt}(\mathrm{IV})$ and $\mathrm{Pd}(\mathrm{II})$ from chloride aqueous solutions was studied. Studies comparing different sorbents will reveal the importance of metal-biomass specificity. The $\mathrm{pH}$ of the solution, the mass of biosorbent, and contact time have been studied in order to find the optimal parameters for biosorption of metals. The Langmuir and Freundlich adsorption isotherms have been used for interpretation of the process equilibrium of $\mathrm{Pt}(\mathrm{IV})$ and $\mathrm{Pd}(\mathrm{II})$ on Aspergillus sp. and Saccharomyces sp. The sorption kinetics of both ions on these microorganisms was also studied. The method was tested for the removal of these 
precious metals from different wastewater samples (sewage and road run-off water). Moreover, it was demonstrated that the quantitative recovery of $\mathrm{Pd}$ from industrial wastes (anode slime) might be obtained using fungal biosorbent.

\section{Materials and Methods}

\subsection{Instrumentation and Measurement Conditions}

A Solaar M6 (Thermo Electron Corporation, Gloucester, UK) atomic absorption spectrometer equipped with an electrothermal atomizer (ETAAS) and a Zeeman background correction system was used. Hollow cathode lamps (CPI International, Santa Rosa, USA) were operated at a current of $10 \mathrm{~mA}$ for Pt and $6 \mathrm{~mA}$ for Pd. The absorbance signals were measured with $0.5 \mathrm{~nm}$ spectral bandpass at $265.9 \mathrm{~nm}$ and $247.6 \mathrm{~nm}$ for Pt and Pd, respectively. Pyrolytically coated graphite tubes were used for atomization of analytes. The time/temperature program for the Pd determination was: drying at $100{ }^{\circ} \mathrm{C}$ for $30 \mathrm{~s}, 110{ }^{\circ} \mathrm{C}$ for $20 \mathrm{~s}$, ashing at $1100{ }^{\circ} \mathrm{C}$ for $20 \mathrm{~s}$ and atomization at $2200{ }^{\circ} \mathrm{C}$ for $3 \mathrm{~s}$. The time/temperature program for the Pt determination was: drying at $100{ }^{\circ} \mathrm{C}$ for $30 \mathrm{~s}, 110{ }^{\circ} \mathrm{C}$ for $20 \mathrm{~s}$, ashing at $1200{ }^{\circ} \mathrm{C}$ for $20 \mathrm{~s}$ and atomization at $2500{ }^{\circ} \mathrm{C}$ for $3 \mathrm{~s}$.

An inoLab pH Level 1 (WTW, Weilheim, Germany) pH meter equipped with an electrode SenTix 21 (WTW, Weilheim, Germany) was used to measure the pH. A centrifuge MPW 312 (MPW Med. Instruments, Warszawa, Poland) was used for separation of biomass from the supernatant. A Hitachi Model S-3000N (Hitachi, Tokyo, Japan) scanning electron microscope equipped with an energy dispersive X-ray microanalysis (EDX) was used to detect metals in the cells.

\subsection{Reagents and Solutions}

Standard solutions of Pt as a hexachloroplatinic (IV) acid (30\%) (POCH, Gliwice, Poland) and Pd as $\mathrm{PdCl}_{2}\left(1 \mathrm{~g} \mathrm{~L}^{-1}\right)$ (SPC SCIENCE, Baie D'Urfé, Quebec, Canada) were used. Stock solutions of Pd(II) and $\mathrm{Pt}(\mathrm{IV})\left(1 \mu \mathrm{g} \mathrm{L}{ }^{-1}\right)$ in $1 \mathrm{~mol} \mathrm{~L}^{-1} \mathrm{HCl}$ were prepared daily from standard solutions. The appropriate working solutions of $\mathrm{Pd}(\mathrm{II})$ and $\mathrm{Pt}(\mathrm{IV})$ used for biosorption studies were prepared by dilution with Milli-Q water (Millipore, Burlington, USA). Hydrochloric acid (37\% Trace Select, Fluka, Lyon, France) and sodium hydroxide (analytical grade, Standard, Lublin, Poland) were used for adjustment of $\mathrm{pH}$ of solutions. Nitric acid (65\% Trace Select, Fluka, Lyon, France) and hydrochloric acid (37\% Trace Select, Fluka, Lyon, France) were used for digestion of samples.

A growth media were Czapek dox agar (Fluka, Buchs, Switzerland) containing sucrose $\left(30 \mathrm{~g} \mathrm{~L}^{-1}\right)$, agar $\left(15 \mathrm{~g} \mathrm{~L}^{-1}\right), \mathrm{NaNO}_{3}\left(3 \mathrm{~g} \mathrm{~L}^{-1}\right), \mathrm{K}_{2} \mathrm{HPO}_{4}\left(1 \mathrm{~g} \mathrm{~L}^{-1}\right), \mathrm{KCl}\left(0.5 \mathrm{~g} \mathrm{~L}^{-1}\right), \mathrm{MgSO}_{4} \cdot 7 \mathrm{H}_{2} \mathrm{O}\left(0.5 \mathrm{~g} \mathrm{~L}^{-1}\right)$, $\mathrm{FeSO}_{4} \cdot 7 \mathrm{H}_{2} \mathrm{O}\left(0.01 \mathrm{~g} \mathrm{~L}^{-1}\right)$, Yeast extract (Fluka, Buchs, Switzerland) (a mixture of amino acids, peptides, water soluble vitamins and carbohydrates), YPG agar (Fluka, Buchs, Switzerland) and $\alpha$-D-glucose (Aldrich, Hamburg, Germany).

\subsection{Preparation of Cells}

Aspergillus sp. isolated from the soil was prepared according to the procedure described in Reference [42]. In short, it was inoculated on solid nutrient medium onto Petri dishes and aerobically incubated at $30{ }^{\circ} \mathrm{C}$ for $72 \mathrm{~h}$. The growth medium: $50 \mathrm{~g} \mathrm{~L}^{-1}$ of Czapek 146 dox agar and $3.89 \mathrm{~g} \mathrm{~L}^{-1}$ of Yeast extract was sterilized by autoclaving $\left(20 \mathrm{~min}\right.$ at $\left.121^{\circ} \mathrm{C}\right)$. Saccharomyces sp. (Saccharomyces cerevisiae, Baker's yeast, type II, (Sigma-Aldrich, Hamburg, Germany) was grown aerobically at $37^{\circ} \mathrm{C}$ for $96 \mathrm{~h}$ in a pre-sterilized $\left(20 \mathrm{~min}\right.$ at $\left.121^{\circ} \mathrm{C}\right)$ solid medium containing: yeast extract, $1 \%(\mathrm{w} / \mathrm{v})$; peptone, $2 \%$ $(\mathrm{w} / \mathrm{v})$; glucose, $2 \%(\mathrm{w} / \mathrm{v})$ and agar, $2 \%(\mathrm{w} / \mathrm{v})$. Biomass of fungi and yeast was scraped from the growth medium and then washed with $5 \mathrm{~mL}$ of $0.12 \mathrm{~mol} \mathrm{~L}^{-1} \mathrm{HCl}$ and $5 \mathrm{~mL}$ of Milli-Q water in order remove growth solution residues and to stabilize the surface activity.

\subsection{Biosorption Studies}

The biosorption of $\mathrm{Pt}(\mathrm{IV})$ and $\mathrm{Pd}(\mathrm{II})$ was studied under batch experimental conditions using $0.1 \mathrm{~g}$ of wet mass (WM) of biosorbent (fungal or yeast cells) and $5 \mathrm{~mL}$ of $0.1 \mathrm{mg} \mathrm{L}^{-1} \mathrm{of} \mathrm{Pt}(\mathrm{IV})$ or 
$0.075 \mathrm{mg} \mathrm{L}^{-1} \mathrm{Pd}(\mathrm{II})$ solutions. The $\mathrm{pH}$ of $\mathrm{Pt}(\mathrm{IV})$ or $\mathrm{Pd}(\mathrm{II})$ solutions was adjusted to the desired value with $0.1 \mathrm{~mol} \mathrm{~L}^{-1} \mathrm{HCl}$ or $0.1 \mathrm{~mol} \mathrm{~L}^{-1} \mathrm{NaOH}$. Next, $0.1 \mathrm{~g}$ of wet biomass was added to $5 \mathrm{~mL}$ of such solution. The suspension of biomass was stirred for $60 \mathrm{~min}$ at temperature $(25 \pm 1)^{\circ} \mathrm{C}$ on a magnetic stirrer and next centrifuged at $4000 \mathrm{rpm}(550 \times \mathrm{g})$ for $10 \mathrm{~min}$. Concentrations of $\mathrm{Pd}(\mathrm{II})$ and $\mathrm{Pt}(\mathrm{IV})$ in supernatants were determined by ETAAS using external calibration graph. In some cases, the $\mathrm{pH}$ of supernatants was also measured. The effect of initial $\mathrm{pH}$ on the retention of analyte on biomass was studied in the $\mathrm{pH}$ range from 0.5 to 11 . The optimum $\mathrm{pH}$ of the $\mathrm{Pt}$ solutions was equal to 2 (for fungi and yeast), while the optimum $\mathrm{pH}$ of the Pd solutions was 2.5 for yeast or 3.5 for fungi. These $\mathrm{pH}$ values were used throughout all biosorption experiments. The effect of biosorbent dosage was studied in the range from 0.025 to $0.5 \mathrm{~g}$ (wet mass). The contact time was varied between $5 \mathrm{~min}$ and $24 \mathrm{~h}$.

To examine the adsorption model, the solutions of $\mathrm{Pt}$ and $\mathrm{Pd}$ of initial concentration between $0.01 \mathrm{mg} \mathrm{L}^{-1}$ and $20 \mathrm{mg} \mathrm{L}^{-1}$ and optimal $\mathrm{pH}$ ( $\mathrm{pH} 2$ for Pt(IV) and $\mathrm{pH} 2.5$ and 3.5 for Pd(II) on yeast and fungi, respectively) were stirred with $0.1 \mathrm{~g}$ of wet biomass for $45 \mathrm{~min}$ at $25^{\circ} \mathrm{C}$. Afterward, the samples were centrifuged at $4000 \mathrm{rpm}$ for $10 \mathrm{~min}$. The initial and final concentrations of $\mathrm{Pt}$ and $\mathrm{Pd}$ in solutions were determined by ETAAS. Each experiment was conducted in triplicate. In order to recalculate the obtained results for dry biosorbent mass, five portions of wet biomass $(0.4 \mathrm{~g})$ were dried at $60{ }^{\circ} \mathrm{C}$ overnight $[37,38]$ and weighted. It was calculated that $0.1 \mathrm{~g}$ of wet biomass is equal to $0.013 \mathrm{~g}$ of dry biomass.

The efficiency of retention of analyte on biomass and metal uptake by biomass were calculated from the following equations [43]:

$$
\begin{gathered}
\mathrm{E}(\%)=\frac{\mathrm{C}_{0}-\mathrm{C}_{\mathrm{e}}}{\mathrm{C}_{0}} \times 100 \% . \\
q_{\exp }=\frac{\mathrm{V}\left(\mathrm{C}_{0}-\mathrm{C}_{\mathrm{e}}\right)}{\mathrm{w}} .
\end{gathered}
$$

where $E$ is the efficiency of analyte retention (in \%), $C_{0}$ is the initial concentration of metal in solution $\left(\mathrm{mg} \mathrm{L}^{-1}\right), \mathrm{C}_{\mathrm{e}}$ is the equilibrium concentration of metal in solution after the biosorption process $\left(\mathrm{mg} \mathrm{L}^{-1}\right)$, $q_{\exp }$ is the experimental equilibrium uptake ( $\mathrm{mg} \mathrm{g}^{-1}$ of dry weight), $\mathrm{V}$ is the solution volume, and $\mathrm{w}$ is the dry weight of biosorbent (g).

Modeling of the isotherm data was attempted using the Langmuir [44] and Freundlich [45] models, which are represented by the following equations:

$$
\begin{gathered}
\text { Langmuir model : } q_{e}=\frac{q_{\max } b \mathrm{C}_{\mathrm{e}}}{1+b \mathrm{C}_{\mathrm{e}}} \\
\text { Freundlich model }: q_{e}=K_{F} \mathrm{C}_{\mathrm{e}}^{\frac{1}{n}}
\end{gathered}
$$

where $q_{e}$ is the amount of adsorbed metal $\left(\mathrm{mg} \mathrm{g}^{-1}\right), \mathrm{C}_{\mathrm{e}}$ is the equilibrium (final) concentration of the metal in solution $\left(\mathrm{mg} \mathrm{L}^{-1}\right), q_{\max }$ is the maximum monolayer sorption capacity $\left(\mathrm{mg} \mathrm{g}^{-1}\right), b$ is the Langmuir equilibrium constant $\left(\mathrm{L} \mathrm{mg}^{-1}\right), K_{F}$ is an empirical constant that provides an indication of the adsorption capacity of biomass, and $n$ is the Freundlich constant, that indicates the intensity of adsorption.

The sorption isotherms were plotted by varying the analyte uptake (q) by biosorbents to the final concentration of $\mathrm{Pt}$ or $\mathrm{Pd}$ in solution after the biosorption process $\left(\mathrm{C}_{\mathrm{e}}\right)$.

Kinetic models are used to identify the adsorption mechanism type in a studied system. Moreover, kinetics studies are necessary to define the optimum conditions for the metal removal process. The pseudo-first and pseudo-second-order models are most often used for studies of biosorption kinetics of platinum group metals [27].

Linear pseudo-first-order model used in this study was:

$$
\ln \left(q_{e}-q_{t}\right)=\ln q_{e}-\mathrm{k}_{1} t
$$


Linear pseudo-second-order model was:

$$
\frac{t}{q_{t}}=\frac{1}{\mathrm{k}_{2} q_{e}^{2}}+\frac{t}{q_{e}}
$$

where $q_{t}$ and $q_{e}\left(\mathrm{mg} \mathrm{g}^{-1}\right)$ are the amounts of adsorbed ion a given time and at equilibrium state, respectively, $\mathrm{k}_{1}$ - is the first-order kinetic rate, $\mathrm{k}_{2}$ - is the second-order kinetic rate $\left(\mathrm{g} \mathrm{mg}^{-1} \mathrm{~min}^{-1}\right)$.

\subsection{SEM-EDX Analysis}

Scanning electron microscopy with energy dispersive X-ray (SEM-EDX) provides information about the presence of various elements in the biosorbent. In this work, $5 \mathrm{~mL}$ of $\mathrm{Pt}(\mathrm{IV})$ or Pd(II) solutions of $20 \mathrm{mg} \mathrm{L}^{-1}(100 \mu \mathrm{g})$ were added separately to $0.1 \mathrm{~g}$ (wet mass) of fungal cells and gently stirred for $72 \mathrm{~h}$. Next, the cells were centrifuged and the supernatant was discarded. Before SEM-EDX analysis all samples were frozen in liquid nitrogen.

\subsection{Samples Used for Recovery Studies}

Samples of sewage were obtained from the sewage treatment plant in Bialystok (Poland). Samples of road run-off were taken from the retention reservoir at the ring road of Bialystok. Pt $\left(100 \mathrm{ng} \mathrm{mL}^{-1}\right)$ and $\mathrm{Pd}\left(75 \mathrm{ng} \mathrm{mL} \mathrm{mL}^{-1}\right)$ was added to the samples and left for $2 \mathrm{~h}$ for equilibration. Then samples were filtered through PVDF discs $(0.45 \mu \mathrm{m}$, Whatman, Maidstone, Wielka Brytania), adjusted to the required $\mathrm{pH}$ with $0.1 \mathrm{~mol} \mathrm{~L}^{-1} \mathrm{HCl}$ and stirred with $0.1 \mathrm{~g}$ of wet biomass for $2 \mathrm{~h}$. The biomass was separated by centrifugation (10 min, $4000 \mathrm{rpm}$ ), washed with $0.01 \mathrm{~mol} \mathrm{~L}-1 \mathrm{HNO}_{3}$ and digested in quartz crucibles with concentrated $\mathrm{HNO}_{3}$ on a laboratory heater. The digested samples were diluted appropriately with MQ water before determination of metals by ETAAS.

The samples of anode slime $(200 \mathrm{mg})$ obtained from the Institute of Non-Ferrous Metals in Gliwice (Poland) were digested in Teflon vessels in a closed digestion microwave system ETHOS PLUS (Milestone, Sorisole, Italy) with $8 \mathrm{~mL}$ of aqua regia. The residue was separated and solutions were transferred into quartz crucibles and evaporated at a hot-place near to dryness with concentrated $\mathrm{HCl}(3 \times 2 \mathrm{~mL})$ and next diluted with Milli-Q water to $15 \mathrm{~mL}$. Samples were filtered through PVDF filters, adjusted to the required $\mathrm{pH}$ and stirred with $0.1 \mathrm{~g}$ of wet biomass for $2 \mathrm{~h}$. Next, the biomass was separated by centrifugation (10 $\mathrm{min} 4000 \mathrm{rpm}$ ) and concentrations of $\mathrm{Pt}$ and $\mathrm{Pd}$ in supernatants were determined by ETAAS.

\section{Results and Discussion}

\subsection{Effect of $\mathrm{pH}$ on Biosorption}

The effect of an initial $\mathrm{pH}$ on the biosorption of $\mathrm{Pt}(\mathrm{IV})$ and $\mathrm{Pd}(\mathrm{II})$ on fungal and yeast biomass was studied at the $\mathrm{pH}$ range from 0.5 to 11.0 (Figure 1). The highest efficiency of biosorption of $\mathrm{Pt}(\mathrm{IV})$ ions on yeast cells was observed at the $\mathrm{pH}$ range from 1.8 to 3.5, while on fungal cells was nearly quantitative $(90 \%-96 \%)$ at the $\mathrm{pH}$ range from 2.0 to 11.0 . The maximal efficiency of biosorption of $\mathrm{Pd}(\mathrm{II})$ ions on yeast (85\%) was obtained at a very narrow range of $\mathrm{pH}$ from 2.0 to 3.0. Low biosorption of analyte occurred both in a strong acidic medium and in solutions of $\mathrm{pH}$ above 4.0. The biosorption of Pd(II) on fungal cells reached the highest values at a $\mathrm{pH}$ range of 4.0-11.0. In all cases, the biosorption of $\mathrm{Pt}(\mathrm{IV})$ and $\mathrm{Pd}(\mathrm{II})$ was lower in strong acidic solutions (at $\mathrm{pH}<1.8$ ). It is apparent that different attractions are responsible for biosorption of metals on the studied microorganisms. Further experiments on biosorption of $\mathrm{Pt}(\mathrm{IV})$ ions were performed at $\mathrm{pH} 2$ on yeast and fungal cells, while of $\mathrm{Pd}(\mathrm{II})$ ions at $\mathrm{pH} 2.5$ on yeast and $\mathrm{pH} 3.5$ on fungal cells. 


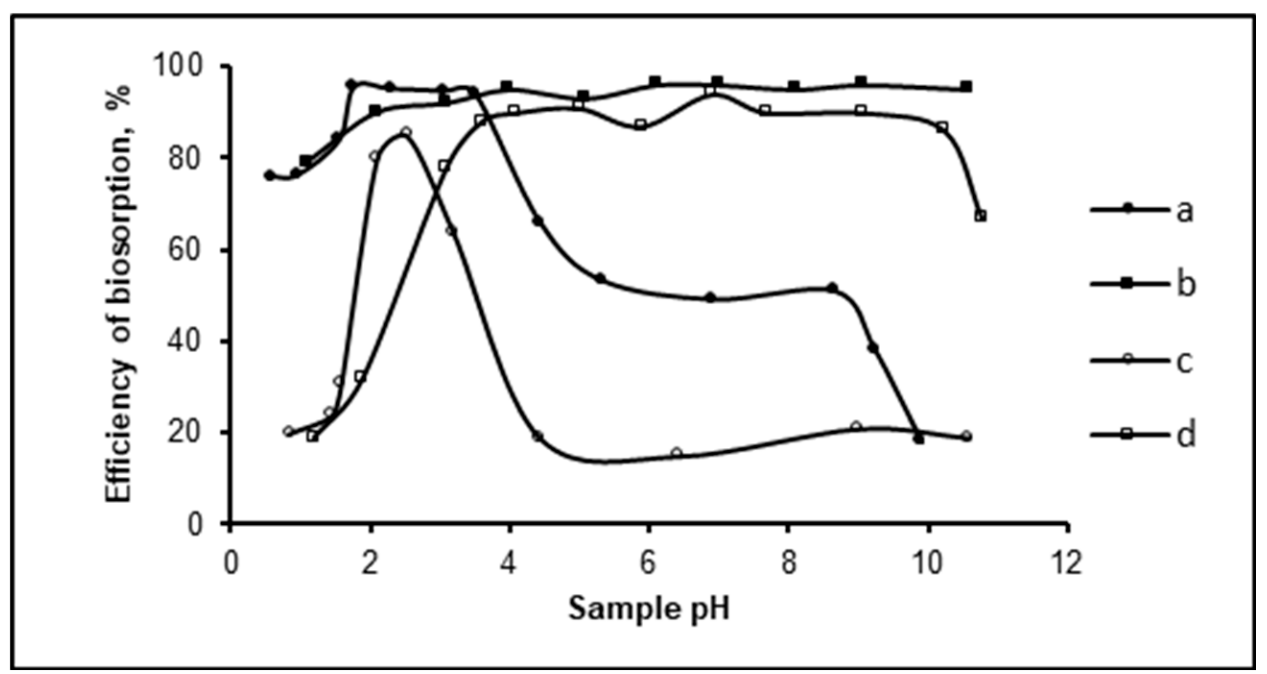

Figure 1. Influence of sample $\mathrm{pH}$ on the efficiency of biosorption of $\mathrm{Pt}\left(0.1 \mathrm{mg} \mathrm{L}^{-1}\right)$ and $\mathrm{Pd}\left(0.075 \mathrm{mg} \mathrm{L}^{-1}\right)$ on yeast Saccharomyces sp. and fungi Aspergillus sp. (contact time $60 \mathrm{~min}$ ): $\mathrm{a}-\mathrm{Pt}(\mathrm{IV})$ on yeast; $\mathrm{b}-\mathrm{Pt}(\mathrm{IV}$ ) on fungi; $\mathrm{c}-\mathrm{Pd}(\mathrm{II})$ on yeast; $\mathrm{d}-\mathrm{Pd}(\mathrm{II})$ on fungi.

Several researchers have also investigated the effect of $\mathrm{pH}$ on the biosorption of $\mathrm{Pt}(\mathrm{IV})$ and $\mathrm{Pd}(\mathrm{II})$ using different microbial mass and comparable results have been reported (Table 1). For instance, biosorption of $\mathrm{Pt}(\mathrm{IV})$ [32,33] and $\mathrm{Pd}(\mathrm{II})$ [33] on free cells of baker's yeast was maximal in acidic media. The similar effect of $\mathrm{pH}$ on the $\mathrm{Pd}(\mathrm{II})$ biosorption was observed on yeast immobilized in calcium alginate. The biosorption of $\mathrm{Pd}(\mathrm{II})$ ions on this sorbent reached the highest values at a $\mathrm{pH}$ range 1.0-2.5 and significantly decreased for less acidic solutions [34].

During the course of the experiments, the $\mathrm{pH}$ of the suspensions before and after the biosorption process of each metal was also measured. It was found that the $\mathrm{pH}$ of $\mathrm{Pt}(\mathrm{IV})$ and $\mathrm{Pd}(\mathrm{II})$ solutions incubated with both microorganisms at $\mathrm{pH} 2-2.5$ slightly increased $(\Delta \mathrm{pH} \sim 0.14)$, while the $\mathrm{pH}$ of suspension incubated without metal ions maintained almost constant $(\Delta \mathrm{pH} \leq 0.05)$. A dissimilar effect was observed during biosorption of $\mathrm{Pd}$ (II) ions by fungal cells (at $\mathrm{pH}$ 3.5), as the $\mathrm{pH}$ of suspension decreased by $0.4 \mathrm{pH}$ unit, while the $\mathrm{pH}$ of suspension incubated without metal ions decreases only by $0.3 \mathrm{pH}$ unit. These phenomena should be discussed in terms of reactions of $\mathrm{Pt}(\mathrm{IV})$ and $\mathrm{Pd}(\mathrm{II})$ ions in aqueous solutions.

It is known that the chemical form of platinum group metals in solutions at the equilibrium state depends on the medium type, the concentration of chloride ions and temperature. In strong acidic media anionic chlorocomplexes of $\mathrm{Pt}(\mathrm{IV})\left(\right.$ as $\left.\mathrm{PtCl}_{6}{ }^{2-}\right)$ and $\mathrm{Pd}(\mathrm{II})\left(\right.$ as $\mathrm{PdCl}_{4}{ }^{2-}$ ) predominate. With the decrease in solution's acidity, the proceeding aquation and hydrolysis reactions cause a formation of different aquachloro- and aquahydroxocomplexes of platinum and palladium $\left(\mathrm{PtCl}_{5}\left(\mathrm{H}_{2} \mathrm{O}\right)^{-}, \mathrm{PdCl}_{4}{ }^{2-}\right.$, $\mathrm{PdCl}_{3}\left(\mathrm{H}_{2} \mathrm{O}\right)^{-}, \mathrm{PdCl}^{+}$and $\left.\mathrm{Pd}(\mathrm{OH})_{2}\right)$, as was shown in References $[19,46]$. Additionally, the chemical composition and acidity of the solution influence the activity and accessibility of functional groups present at the surface of the cell's wall. 
Table 1. Biosorption conditions and parameters of isotherm adsorption models of $\mathrm{Pd}(\mathrm{II})$ and $\mathrm{Pt}(\mathrm{IV})$ on various microorganisms.

\begin{tabular}{|c|c|c|c|c|c|}
\hline \multirow{2}{*}{ Microorganism } & \multirow{2}{*}{ Biosorption Conditions } & \multicolumn{2}{|c|}{ Parameters of Equilibrium Isotherm Models } & \multirow{2}{*}{ Application } & \multirow{2}{*}{ Ref } \\
\hline & & Langmuir & Freundlich & & \\
\hline $\begin{array}{l}\text { Tobacco mosaic virus } \\
\text { Tobacco mosaic virus-wild }\end{array}$ & $\begin{array}{l}\text { Sample } \mathrm{pH}: 5-5.5 \\
\text { contact time: } 1 \mathrm{~h} \\
\text { biomass: } 0.038 \mathrm{~g} \mathrm{~L}^{-1} \\
\text { temperature: } 50{ }^{\circ} \mathrm{C}\end{array}$ & $\begin{array}{c}\text { (Pd) } R^{2}: 0.95 \\
\text { qmax: } 368.21 \mathrm{mg} \mathrm{g}^{-1} \\
\text { b: } 0.36 \mathrm{~L} \mathrm{~m}^{-1} \\
\text { (Pd) } \mathrm{R}^{2}: 0.98 \\
\text { qmax: } 312.87 \mathrm{mg} \mathrm{g}^{-1} \\
\text { b: } 0.12 \mathrm{~L} \mathrm{mg}^{-1}\end{array}$ & - & Standard solutions & [13] \\
\hline $\begin{array}{c}\text { Polyethylenimine } \\
\text { (PEI)-modified Escherichia coli }\end{array}$ & $\begin{array}{c}\text { Sample } \mathrm{pH} \text { : extremely acidic condition } \\
\text { contact time: } 60 \mathrm{~min} \\
\text { biomass: } 0-1.8 \mathrm{~g} \\
\text { temperature: } 25^{\circ} \mathrm{C}\end{array}$ & $\begin{array}{c}(\mathrm{Pt}) \mathrm{R}^{2}: 0.965 \\
\text { qmax: } 108.8 \mathrm{mg} \mathrm{g}^{-1} \\
\text { b: } 0.0014 \mathrm{~L} \mathrm{mg}^{-1}\end{array}$ & $\begin{array}{l}(\mathrm{Pt}) \mathrm{R}^{2}: 0.952 \\
\mathrm{~K}_{\mathrm{F}}: 1.465 \mathrm{~L} \mathrm{~g}^{-1} \\
\mathrm{n}: 1.835\end{array}$ & ICP wastewater & [23] \\
\hline Escherichia coli & $\begin{array}{l}\text { Sample } \mathrm{pH}: 1.2 \\
\text { contact time: } 24 \mathrm{~h} \\
\text { biomass: } 0.06 \mathrm{~g} \\
\text { temperature: } 25^{\circ} \mathrm{C}\end{array}$ & $\begin{array}{c}\text { (Pd) } \mathrm{R}^{2}: 0.962 \\
\mathrm{q}_{\max }: 38.87 \mathrm{mg} \mathrm{g}^{-1} \\
\text { b: } 0.48 \mathrm{~L} \mathrm{mg}^{-1} \\
(\mathrm{Pt}) \mathrm{R}^{2}: 0.991 \\
\text { qmax: }_{\max } 45.65 \mathrm{mg} \mathrm{g}^{-1} \\
\text { b: } 0.58 \mathrm{~L} \mathrm{mg}^{-1}\end{array}$ & & $\begin{array}{l}\text { Single and binary } \\
\text { standard solutions }\end{array}$ & [26] \\
\hline Desulfovibrio desulfufricans & $\begin{array}{l}\text { Sample } \mathrm{pH}: 3 \\
\text { contact time: } 20 \mathrm{~min} \\
\text { biomass: } 0.0015 \mathrm{~g} \\
\text { temperature: } 30^{\circ} \mathrm{C}\end{array}$ & $\begin{array}{c}(\mathrm{Pd}) \\
\mathrm{q}_{\max }: 125.0 \mathrm{mg} \mathrm{g}^{-1} \\
\text { b: } 1.21 \mathrm{~L} \mathrm{mg}^{-1} \\
(\mathrm{Pt}) \\
\text { qmax: } 62.5 \mathrm{mg} \mathrm{g}^{-1} \\
\text { b: } 0.50 \mathrm{~L} \mathrm{mg}^{-1}\end{array}$ & $\begin{array}{c}(\mathrm{Pd}) \\
\mathrm{K}_{\mathrm{F}}: 69.7 \mathrm{~L} \mathrm{~g}^{-1} \\
\text { n: } 4.24 \\
(\mathrm{Pt}) \\
\mathrm{K}_{\mathrm{F}}: 24.2 \mathrm{~L} \mathrm{~g}^{-1} \\
\text { n: } 3.43\end{array}$ & Standard solutions & [25] \\
\hline
\end{tabular}


Table 1. Cont

\begin{tabular}{|c|c|c|c|c|c|}
\hline \multirow{2}{*}{ Microorganism } & \multirow{2}{*}{ Biosorption Conditions } & \multicolumn{2}{|c|}{ Parameters of Equilibrium Isotherm Models } & \multirow{2}{*}{ Application } & \multirow{2}{*}{ Ref. } \\
\hline & & Langmuir & Freundlich & & \\
\hline Desulfovibrio fructodivorans & & $\begin{array}{c}(\mathrm{Pd}) \\
\mathrm{q}_{\max }: 119.8 \mathrm{mg} \mathrm{g}^{-1} \\
\text { b: } 0.12 \mathrm{~L} \mathrm{mg}^{-1} \\
(\mathrm{Pt}) \mathrm{R}^{2}: \\
\mathrm{q}_{\max }: 32.3 \mathrm{mg} \mathrm{g}^{-1} \\
\mathrm{~b}: 1.17 \mathrm{~L} \mathrm{mg}^{-1}\end{array}$ & $\begin{array}{c}(\mathrm{Pd}) \\
\mathrm{K}_{\mathrm{F}}: 10.4 \mathrm{~L} \mathrm{~g}^{-1} \\
\mathrm{n}: 2.35 \\
(\mathrm{Pt}) \\
\mathrm{K}_{\mathrm{F}}: 20.3 \mathrm{~L} \mathrm{~g}^{-1} \\
\mathrm{n}: 7.12\end{array}$ & & [25] \\
\hline Desulfovibrio vulgaris & & $\begin{array}{c}(\mathrm{Pd}) \\
\mathrm{q}_{\max }: 106.3 \mathrm{mg} \mathrm{g}^{-1} \\
\text { b: } 0.66 \mathrm{~L} \mathrm{mg}^{-1} \\
(\mathrm{Pt}) \\
\mathrm{q}_{\max }: 32.1 \mathrm{mg} \mathrm{g}^{-1} \\
\text { b: } 0.42 \mathrm{~L} \mathrm{mg}^{-1}\end{array}$ & $\begin{array}{c}(\mathrm{Pd}) \\
\mathrm{K}_{\mathrm{F}}: 41.9 \mathrm{~L} \mathrm{~g}^{-1} \\
\text { n: } 3.73 \\
(\mathrm{Pt}) \\
\mathrm{K}_{\mathrm{F}}: 16.8 \mathrm{~L} \mathrm{~g}^{-1} \\
\text { n: } 5.92\end{array}$ & & [25] \\
\hline Providencia vermicola & $\begin{array}{l}\text { Sample pH: } 4 \\
\text { contact time: } 3 \mathrm{~h} \\
\text { biomass: } 0.075 \mathrm{~g} \\
\text { temperature: } 30^{\circ} \mathrm{C}\end{array}$ & $\begin{array}{c}\text { (Pd) } \mathrm{R}^{2}: 0.95 \\
\mathrm{q}_{\max }: 119 \mathrm{mg} \mathrm{g}^{-1} \\
\text { b: } 0.1 \mathrm{~L} \mathrm{mg}^{-1} \\
\text { (Pt) } \mathrm{R}^{2}: 0.97 \\
\text { qmax }^{2} 30.2 \mathrm{mg} \mathrm{g}^{-1} \\
\text { b: } 0.13 \mathrm{Lg}^{-1}\end{array}$ & $\begin{array}{c}\text { (Pd) R } \mathrm{R}^{2}: 0.78 \\
\mathrm{~K}_{\mathrm{F}}: 1.27 \mathrm{~L} \mathrm{~g}^{-1} \\
1 / \mathrm{n}: 1.07 \\
(\mathrm{Pt}) \mathrm{R}^{2}: 0.72 \\
\mathrm{~K}_{\mathrm{F}}: 0.16 \mathrm{~L} \mathrm{~g}^{-1} \\
1 / \mathrm{n}: 1.06\end{array}$ & $\begin{array}{l}\text { Single and binary } \\
\text { standard solutions }\end{array}$ & [27] \\
\hline Saccharomyces sp. & $\begin{array}{c}\text { Sample pH: }(\mathrm{Pd}) 2.5,(\mathrm{Pt}) 2 \\
\text { contact time: } 45 \mathrm{~min} \\
\text { biomass: } 0.1 \mathrm{~g} \text { (wet), } 0.013 \mathrm{~g} \text { (dry) } \\
\text { temperature: } 25^{\circ} \mathrm{C}\end{array}$ & $\begin{array}{c}\text { (Pd) R } \mathrm{R}^{2}: 0.9874 \\
\text { qmax}_{\max }: 0.042 \mathrm{mg} \mathrm{g}^{-1} \\
\text { b: } 0.0204 \mathrm{~L} \mathrm{mg}^{-1} \\
(\mathrm{Pt}) \mathrm{R}^{2}: 0.9860 \\
\text { qmax: } 0.185 \mathrm{mg} \mathrm{g}^{-1} \\
\text { b: } 0.0068 \mathrm{~L} \mathrm{mg}^{-1}\end{array}$ & $\begin{array}{c}(\mathrm{Pd}) \mathrm{R}^{2}: 0.797 \\
\mathrm{~K}_{\mathrm{F}}: 0.095 \mathrm{~L} \mathrm{~g}^{-1} \\
\mathrm{n}: 1.630 \\
(\mathrm{Pt}) \mathrm{R}^{2}: 0.975 \\
\mathrm{~K}_{\mathrm{F}}: 0.286 \mathrm{~L} \mathrm{~g}^{-1} \\
\mathrm{n}: 1.505\end{array}$ & Standard solutions & This study \\
\hline Aspergillus sp. & $\begin{array}{c}\text { Sample pH: }(\mathrm{Pd}) 3.5,(\mathrm{Pt}) 2 \\
\text { contact time: } 45 \mathrm{~min} \\
\text { biomass: } 0.1 \mathrm{~g} \text { (wet), } 0.013 \mathrm{~g} \text { (dry) } \\
\text { temperature: } 25^{\circ} \mathrm{C}\end{array}$ & $\begin{array}{c}\text { (Pd) } R^{2}: 0.9823 \\
\text { qmax: } 4.277 \mathrm{mg} \mathrm{g}^{-1} \\
\text { b: } 0.0021 \mathrm{~L} \mathrm{mg}^{-1} \\
(\mathrm{Pt}) \mathrm{R}^{2} 0.0010 \\
\text { qmax }: 5.488 \mathrm{mg} \mathrm{g}^{-1} \\
\text { b: } 0.0006 \mathrm{~L} \mathrm{mg}^{-1}\end{array}$ & $\begin{array}{c}\text { (Pd) } R^{2}: 0.805 \\
\mathrm{~K}_{\mathrm{F}}: 2.842 \mathrm{~L} \mathrm{~g}^{-1} \\
\mathrm{n}: 1.485 \\
(\mathrm{Pt}) \mathrm{R}^{2}: 0.962 \\
\mathrm{~K}_{\mathrm{F}}: 1.766 \mathrm{~L} \mathrm{~g}^{-1} \\
\text { n: } 1.164\end{array}$ & $\begin{array}{l}\text { Run-off water, sewage, } \\
\text { anode slime }\end{array}$ & \\
\hline
\end{tabular}


The high biosorption of platinum and palladium on yeast cells at $\mathrm{pH}$ range from 1.8 to 3.0 occurs probably through electrostatic attractions between the protonated functional groups of the sorbent and their anionic chlorocomplexes. It was reported that the zeta potential of Saccharomyces sp. immobilized on cone biomass was positive at $\mathrm{pH} 2.0$ and the overall surface of the biomass was negatively charged at the $\mathrm{pH}$ values between 3.0 and 7.0 [47]. Other studies [48] have shown, that the surface of free cells of yeast was negatively charged for $\mathrm{pH}$ higher than 3.5 favoring adsorption of cationic species. Lower sorption of $\mathrm{Pt}(\mathrm{IV})$ and $\mathrm{Pd}(\mathrm{II})$ observed in strong acidic medium is an effect of competing of chloride ions and anionic chlorocomplexes of platinum and palladium present in the solution for the protonated functional groups of yeast's cell wall. The results presented above imply that the biosorption mechanism could be based on electrostatic attractions between analytes and microorganisms. In our former studies [35] platinum was efficiently $(83 \%)$ removed from immobilized yeast with $3 \mathrm{~mol} \mathrm{~L}^{-1}$ $\mathrm{NaCl}$, showing that ion-exchange mechanism could be also involved in the metal binding to biomass. However, in our opinion, other kinds of interactions may also participate in biosorption of $\mathrm{Pt}$, as above $91 \%$ of platinum was recovered from the same sorbent with an acidic solution of thiourea [34]. A complex mechanism, likewise, initial non-specific sorption of platinum ions due to electrostatic attractions between protonated sorbent and platinum anions followed by chemical sorption of $\mathrm{Pt}(\mathrm{IV})$ by S. cerevisiae was suggested by Mack et al. [32]. Kim et al. [26] stated that primary amines present in the biomass are responsible for selective biosorption of $\mathrm{Pd}(\mathrm{II})$ and $\mathrm{Pt}(\mathrm{IV})$ by E. coli. Moreover, the affinity of amines toward the Pd(II) was much higher than for Pt(IV) ions.

The attractions between $\mathrm{Pt}(\mathrm{IV}), \mathrm{Pd}(\mathrm{II})$ and fungi cells are also complex in their nature including electrostatic attractions of anionic complexes to the positively charged amino groups (at a lower $\mathrm{pH}$ range) and complexation of neutral or cationic forms of their aqua- and aquahydroxochloro-complexes to functional groups of cell wall from neutral and basic solutions. The effect of modification of a fungal cell wall by acidic solution has to be also considered. The initial studies (data not shown) were performed on the effect of modification of fungal cells (washing with MQ water, washing with $0.12 \mathrm{~mol} \mathrm{~L}^{-1} \mathrm{HCl}$ and next $\mathrm{MQ}$ water, boiling with $0.5 \mathrm{~mol} \mathrm{~L}^{-1} \mathrm{NaOH}$ and next washing with $\mathrm{MQ}$ water) on the biosorption of platinum and palladium. The experiments showed that biosorption of both metals from solutions of $\mathrm{pH}>4$ on the fungi washed with water and modified with $\mathrm{NaOH}$ was significantly lower (biosorption efficiency from 5\% to $40 \%$ ) than on the fungi modified with an acid solution (biosorption efficiency $>90 \%$ ). The efficient retention of $\mathrm{Pt}$ and $\mathrm{Pd}$ on fungi treated by each procedure occurred from solutions of $\mathrm{pH} 2-4$. These results cannot be easily compared to literature data as the research on biosorption of precious metals on fungi is mainly focused on gold [9]. Gold and other heavy metals, e.g., copper, cadmium and lead, are retained on Aspergillus sp. biomass in weakly acidic or neutral $\mathrm{pH}$ [2,37-39]. Hence, in our further work, in order to achieve better selectivity of removal of precious metals from samples containing other metals, the studies were carried out at $\mathrm{pH} 2.0$ for $\mathrm{Pt}(\mathrm{IV})$ and 3.5 for $\mathrm{Pd}(\mathrm{II})$. At $\mathrm{pH} \geq 3$ biosorption of $\mathrm{Pd}(\mathrm{II})$ ions in the form of $\mathrm{PdCl}^{+}$and $\mathrm{Pd}(\mathrm{OH})_{2}$ species [19] may occur. The increase of the concentration of $\mathrm{H}^{+}$ions in cells suspension after the biosorption process suggests that $\mathrm{Pd}(\mathrm{II})$ ions could be bound by an ion-exchange mechanism.

\subsection{Effect of Contact Time and Biomass Dosage}

The effect of contact time on the biosorption of $\mathrm{Pt}(\mathrm{IV})$ and $\mathrm{Pd}(\mathrm{II})$ ions on yeast and fungal biomass was studied in the range from $5 \mathrm{~min}$ to $24 \mathrm{~h}$. About $60 \%$ of $\mathrm{Pd}(\mathrm{II})$ was taken up by yeast within the first $10 \mathrm{~min}$, and after $45 \mathrm{~min}$ the amount of biosorbed $\mathrm{Pd}$ (II) reached a constant value of $90.1 \% \pm 0.7 \%$. The biosorption of $\mathrm{Pt}(\mathrm{IV})$ on yeast was faster, as above $93 \%$ of the initial amount of ions was retained within 5 min of contact time. These results are consistent with the results of Mack et al. [32], who observed the rapid platinum removal during the first $5 \mathrm{~min}$. Next, the process, identified as chemical sorption, was much slower. The efficiency of biosorption of $\mathrm{Pd}(\mathrm{II})$ and $\mathrm{Pt}(\mathrm{II})$ on fungi within $15 \mathrm{~min}$ reached $97 \%$ and $91 \%$, respectively. Figure 2a reveals that over $80 \%$ of biosorption of both ions occurred within 15-20 min and the equilibrium was attained within $45 \mathrm{~min}$. The reproducibility of the biosorption process $(n=6)$ on fungal biomass was $89.0 \pm 1.4 \%$ for $\mathrm{Pt}(\mathrm{IV})$ and $96.0 \pm 3.8 \%$ for 
$\operatorname{Pd}(\mathrm{II})$, while on yeast biomass was $94.1 \pm 1.6 \%$ for $\mathrm{Pt}(\mathrm{IV})$ and $84.3 \pm 4.7 \%$ for $\mathrm{Pd}(\mathrm{II})$. There was no remarkable change in the amount of metal taken up after $24 \mathrm{~h}$ of contact time. The time required to reach the biosorption equilibrium of other metals ions on fungi Aspergillus sp. [37-39] and yeast Saccharomyces sp. [47-49] was longer than that found in this work. The equilibrium time between platinum or palladium and moss biomass was comparable [21] but this time was much longer for other biomaterials (in the range 24-96 h) [17,20,22]. In practice, a sorbent with a faster uptake is better for the removal of metals.

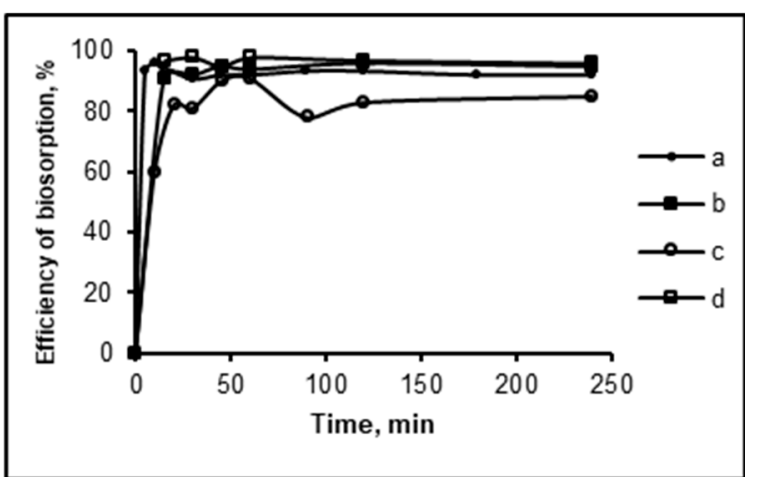

(a)

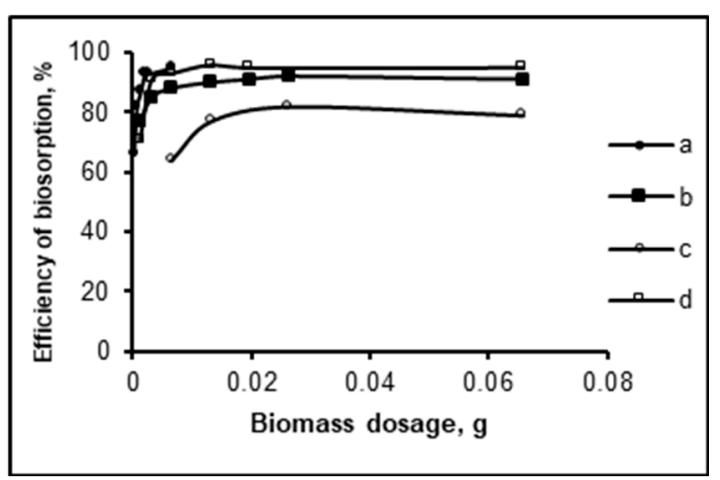

(b)

Figure 2. Dependency of the efficiency of biosorption of Pt $\left(0.1 \mathrm{mg} \mathrm{L}^{-1}\right)$ and $\mathrm{Pd}\left(0.075 \mathrm{mg} \mathrm{L}^{-1}\right)$ at optimal pH conditions on Saccharomyces sp. and Aspergillus sp. on (a) contact time (b) biosorbent mass (contact time $45 \mathrm{~min}$ ); a-Pt(IV) on yeast; b-Pt(IV) on fungi; $\mathrm{c}-\mathrm{Pd}(\mathrm{II})$ on yeast; $\mathrm{d}-\mathrm{Pd}(\mathrm{II})$ on fungi.

The influence of biomass dosage on $\mathrm{Pt}(\mathrm{IV})$ and $\mathrm{Pd}(\mathrm{II})$ biosorption was studied in the range of $0.001-0.066 \mathrm{~g}$ of dry mass (0.025-0.5 g of wet mass) (Figure $2 \mathrm{~b})$. The biosorption efficiency of both ions increases along with the increasing mass of biomass to a value of $0.013 \mathrm{~g}$ ( $0.1 \mathrm{~g}$ of wet mass). This is probably an effect of a higher number of binding sites on the surface of the biosorbent. The efficiency of biosorption was constant in the range of $0.013-0.066 \mathrm{~g}$ of biomass dosage demonstrating the formation of an equilibrium between the ions bound to the biosorbent and those remaining in the solution.

\subsection{Biosorption Isotherms}

The equilibrium biosorption isotherm is of importance in the design of sorption systems. The Langmuir isotherm is based on the monolayer adsorption on the active sites of the adsorbent. The Freundlich isotherm explains the adsorption on a heterogeneous (multiple layers) surface with uniform energy. Although the empirical models cannot provide any mechanistic understanding of the adsorption phenomena, these models may be used to conveniently estimate the maximum uptake of precious metals from experimental data.

The experimental sorption isotherms obtained under optimal conditions and the sorption isotherms predicted by the Langmuir and Freundlich models along with the determination coefficients $\left(R^{2}\right)$ are shown in Figure 3. The calculated Langmuir and Freundlich parameters are listed in Table 1. The values of $\mathrm{R}^{2}$, which were found to be above 0.982 , indicating that the biosorption of $\mathrm{Pt}$ and $\mathrm{Pd}$ on the fungi and yeast biomass is consistent with the Langmuir model. In other words, monolayer adsorption took place at the binding sites of both microorganisms. Both types of microorganisms have a higher affinity for $\mathrm{Pd}(\mathrm{II})$ than for $\mathrm{Pt}(\mathrm{IV})$ ions. The highest affinity of the sorbent for the sorbate was observed between the yeast and the $\mathrm{Pd}(\mathrm{II})$ ions (the highest $\mathrm{b}$ constant). Fungi Aspergillus sp. show a higher adsorption capacity then yeast Saccharomyces sp. for both metals. According to the Langmuir model, the fungi achieved a maximum platinum uptake of $5.488 \mathrm{mg} \mathrm{g}^{-1}$ that was 30-fold higher than that of the yeast biomass $\left(0.185 \mathrm{mg} \mathrm{g}^{-1}\right)$. The specific palladium sorption capacity of fungi $\left(4.277 \mathrm{mg} \mathrm{g}^{-1}\right)$ was 100 -fold higher than that of yeast. This is most likely related to the composition of the cell wall of Aspergillus sp., which enhances the adsorption capacity. As can be seen, fungi exhibit an advantage in the removal 
of Pt and Pd compared with yeast. Hence, further studies were performed on Aspergillus sp. cells. The specified sorption of Pt(IV) and Pd(II) to fungi cells was confirmed by EDX analysis (Figure $4 b, c$ ). The signal of Pt is seen at $2 \mathrm{keV}$ and $\mathrm{Pd}$ at $2.8 \mathrm{keV}$ and $0.2 \mathrm{keV}$ (covered by the peak of C).
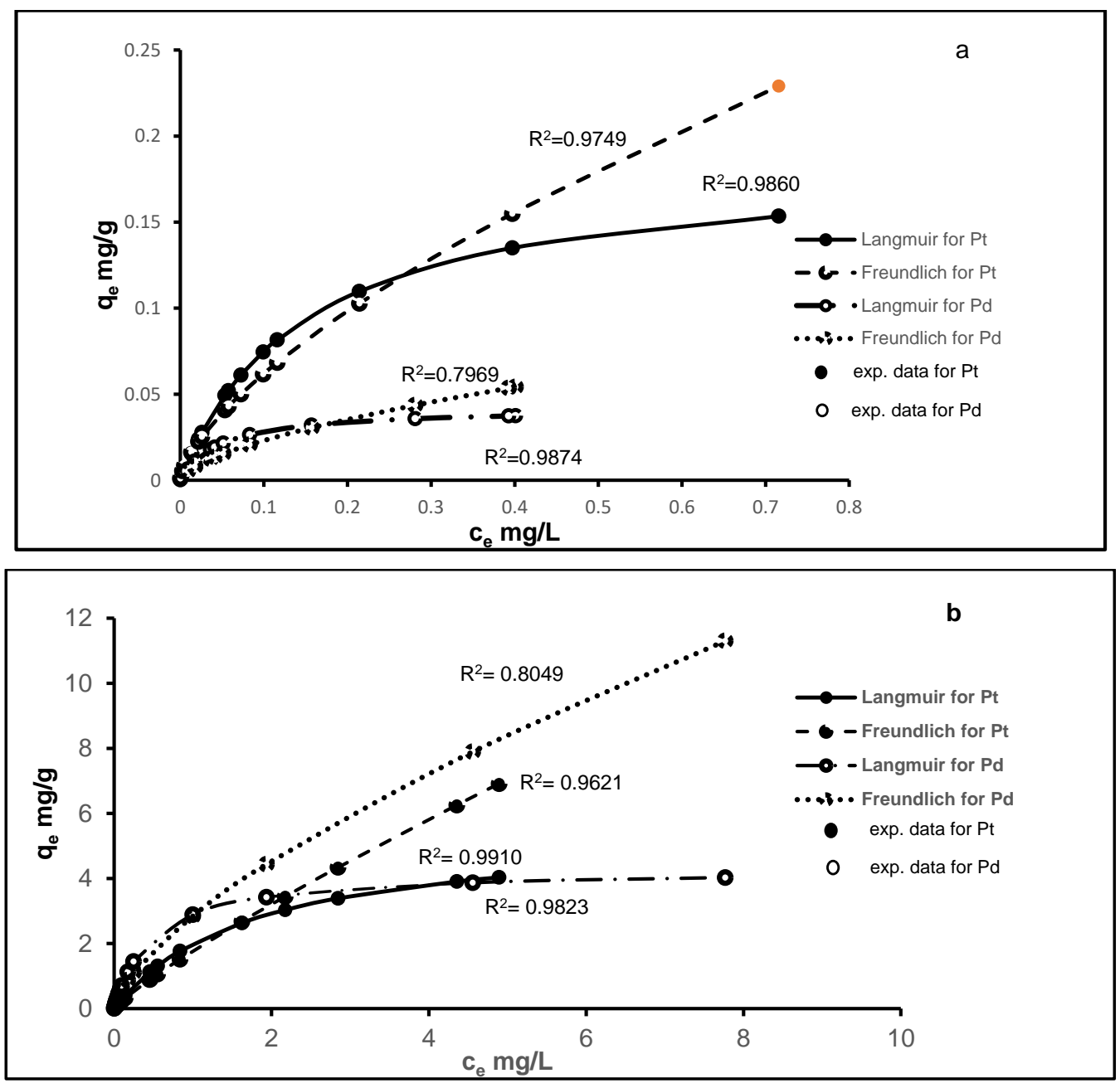

Figure 3. Sorption isotherms of Pt and Pd on (a) Saccharomyces sp. and (b) Aspergillus sp. Biosorption of $\mathrm{Pt}$ on yeast and fungi at $\mathrm{pH}$ 2, biosorption of $\mathrm{Pd}$ on yeast at $\mathrm{pH} 2.5$, on fungi at $\mathrm{pH} 3.5$, dry biomass $0.013 \mathrm{~g}$, contact time $45 \mathrm{~min}$.

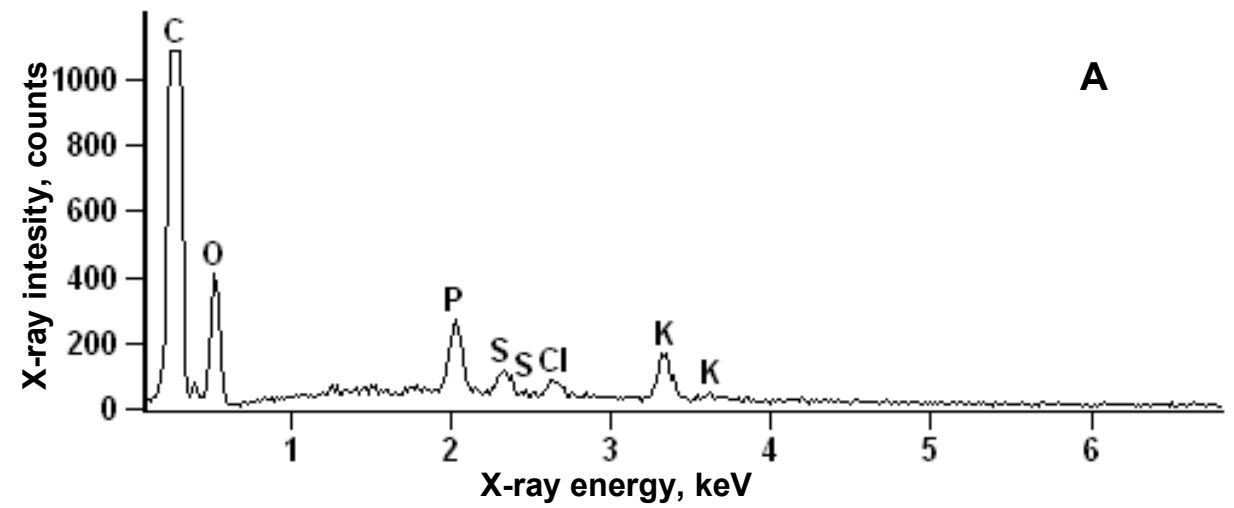

(a)

Figure 4. Cont. 


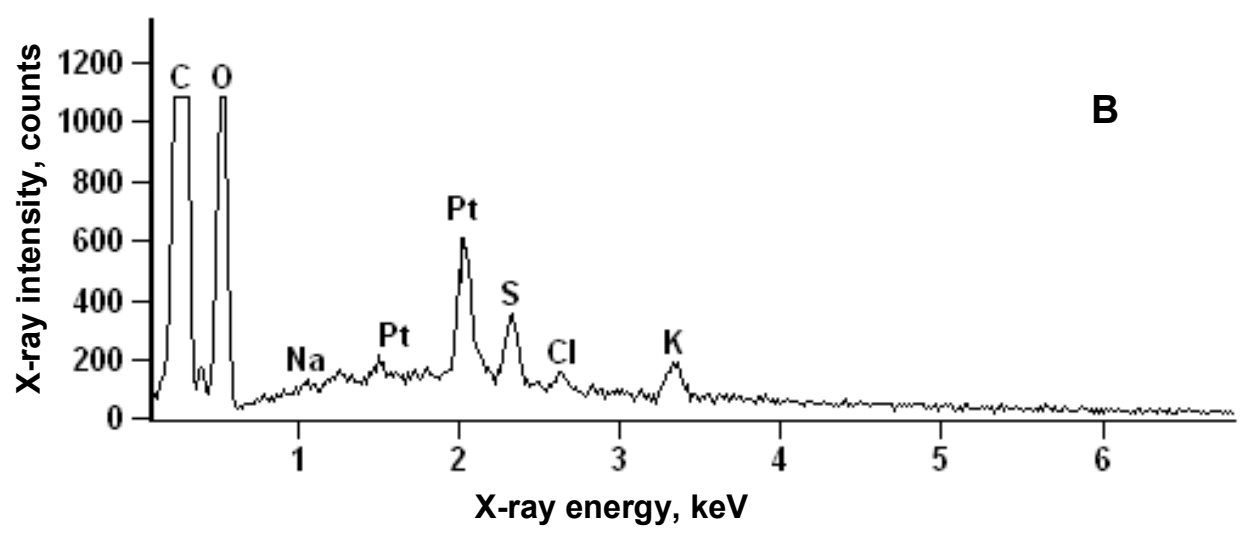

(b)

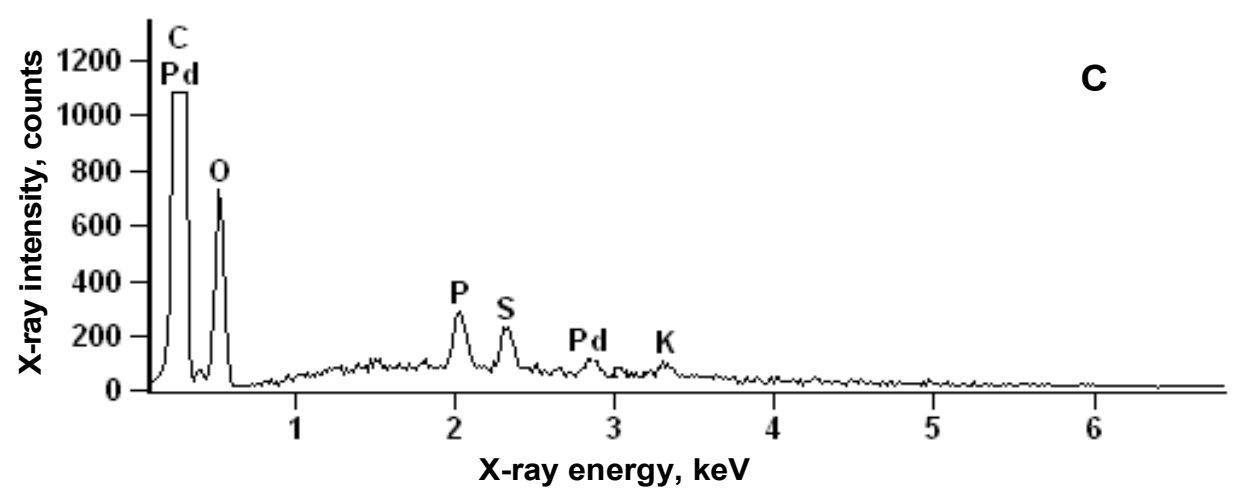

(c)

Figure 4. SEM-EDS spectra of (a) free fungi cells, (b) fungi after incubation with $\mathrm{Pt}(\mathrm{IV})$, (c) fungi after incubation with $\operatorname{Pd}(\mathrm{II})$.

The review of biosorption conditions and parameters of isotherm adsorption models of $\mathrm{Pd}(\mathrm{II})$ and $\mathrm{Pt}(\mathrm{IV})$ on various microorganisms as well as results obtained in this work are given for comparison in Table 1. As can be seen, the maximum biosorption capacities of fungi observed in our experiment are lower in comparison with the sorption capacities of other microorganisms. However, the time required to obtain the equilibrium of the biosorption process was shorter than in other works.

\subsection{Biosorption Kinetics}

In order to complete evaluation of the sorption mechanism of examined biomaterials, the kinetic parameters of the sorption process were determined. For this purpose, sorption studies of $\mathrm{Pt}$ or $\mathrm{Pd}$ ions were carried out under optimal conditions using $0.1 \mathrm{~g}$ (wet biomass) of the currently tested biosorbent. The applied concentration of Pt was $0.1 \mathrm{mg} \mathrm{L}^{-1}$, while Pd was $0.075 \mathrm{mg} \mathrm{L}^{-1}$. Every $15 \mathrm{~min}$ an appropriate amount of the tested suspension was taken and the current content of the studied ion was determined. The pseudo-first (PFO) and -second (PSO) models of adsorption kinetics were assumed and checked [50]. Basic kinetic parameters such as the amount of adsorbed metal ions at equilibrium $\left(q_{e}\right)$ and the adsorption rate constants $\left(k_{1}\right.$ and $\left.k_{2}\right)$ were determined experimentally using the graphical dependence of $\log \left(q_{e}-q_{t}\right)$ vs. $t$ for the PFO and $1 / q_{t}$ vs. $1 / t$ for the PSO models of adsorption kinetics. The suitability of experimental data to the assumed model of adsorption kinetics was determined based on the regression coefficient. The obtained kinetic parameters of examined processes are presented in Table 2.

The obtained data show that the kinetics of the Pt and Pd adsorption process suit well the pseudo-second order kinetics model. This means that rate-limiting step most likely involves chemical interactions leading to the binding of metal ions to the adsorbent surface such as, among others, ion 
exchange or complexing processes [50]. This conclusion confirms results obtained by the examination of adsorption isotherms. The mass of adsorbed ion at equilibrium state calculated for the dry mass of biosorbent was $7.819 \times 10^{-2} \mathrm{mg} \mathrm{g}^{-1}$ and $5.864 \times 10^{-2} \mathrm{mg} \mathrm{g}^{-1}$ for Pt and Pd ions, respectively.

Table 2. The kinetic parameters of Pt and Pd adsorption by examined biosorbents $\left(q_{e}\right.$-the amount of adsorbed ion at equilibrium state $\left(\mathrm{mg} \mathrm{g}^{-1}\right), k_{1}$-the first order kinetic rate $\left(\mathrm{min}^{-1}\right) ; k_{2}$-second order kinetic rate $\left(\mathrm{g} \mathrm{mg}^{-1} \mathrm{~min}^{-1}\right)$.

\begin{tabular}{|c|c|c|c|c|c|}
\hline Studied Ion & Microrganism & Pseudo-I & Kinetics Model & Pseudo-S & Kinetics Model \\
\hline \multirow{6}{*}{$\mathrm{Pt}$} & \multirow{3}{*}{ Saccharomyces sp. } & $q_{e}$ & $4.670 \times 10^{-3}$ & $q_{e}$ & $4.601 \times 10^{-3}$ \\
\hline & & $k_{1}$ & $8 \times 10^{-5}$ & $k_{2}$ & 830.173 \\
\hline & & $\mathrm{R}^{2}$ & 0.145 & $\mathrm{R}^{2}$ & 0.999 \\
\hline & \multirow{3}{*}{ Aspergillus sp. } & $q_{e}$ & $0.358 \times 10^{-4}$ & $q_{e}$ & $4.122 \times 10^{-3}$ \\
\hline & & $k_{1}$ & $2.2 \times 10^{-3}$ & $k_{2}$ & 210.474 \\
\hline & & $\mathrm{R}^{2}$ & 0.373 & $R^{2}$ & 0.999 \\
\hline \multirow{6}{*}{$\mathrm{Pd}$} & \multirow{3}{*}{ Saccharomyces sp. } & $q_{e}$ & 1106.0 & $q_{e}$ & $3.188 \times 10^{-3}$ \\
\hline & & $k_{1}$ & $5.1 \times 10^{-3}$ & $k_{2}$ & 226.254 \\
\hline & & $\mathrm{R}^{2}$ & 0.515 & $\mathrm{R}^{2}$ & 0.990 \\
\hline & \multirow{3}{*}{ Aspergillus sp. } & $q_{e}$ & $3.218 \times 10^{-3}$ & $q_{e}$ & $3.092 \times 10^{-3}$ \\
\hline & & $k_{1}$ & $2 \times 10^{-4}$ & $k_{2}$ & 280.620 \\
\hline & & $R^{2}$ & 0.491 & $\mathrm{R}^{2}$ & 0.996 \\
\hline
\end{tabular}

\subsection{Recovery of Platinum and Palladium from Wastes}

The presence of matrix components of the samples, inorganic ions as well as organic matter, may influence the specific biosorption of analyte. Hence, in this work, the recovery of platinum and palladium ions from samples containing complex matrix was studied. As the content of $\mathrm{Pt}$ and $\mathrm{Pd}$ in samples of crude sewage obtained from municipal sewage treatment plant and road run-off was not determined, they were spiked with different amounts of analytes and left for equilibration. Next, they were pretreated and analyzed according to the procedure described in Section 2.6. The efficiencies of retention of analytes and their recoveries from biomass were calculated and the results are given in Tables 3 and 4 .

Table 3. Application of fungi Aspergillus sp. for separation of $\mathrm{Pt}(\mathrm{IV})$ from various samples (sample $\mathrm{pH}$

2, mass of biosorbent $0.1 \mathrm{~g}$, contact time $2 \mathrm{~h}$, washing agent: $0.01 \mathrm{~mol} \mathrm{~L}^{-1} \mathrm{HNO}_{3}, \mathrm{n}=3$ ).

\begin{tabular}{cccc}
\hline Sample Type & Pt(IV) Amount, $\boldsymbol{\mu g}$ & Retention \pm SD, $\%$ & Recovery \pm SD, $\%$ \\
\hline Standard solution & 100 & $89.1 \pm 1.1$ & $70.9 \pm 2.5$ \\
& 200 & $81.3 \pm 0.8$ & $65.3 \pm 4.3$ \\
& 500 & $68.1 \pm 6.0$ & $66.5 \pm 4.3$ \\
& 1000 & $56.5 \pm 1.7$ & $51.3 \pm 5.2$ \\
\hline Road run-off & 0.5 & $95.6 \pm 0.9$ & $68.9 \pm 2.1$ \\
& 100 & $90.7 \pm 0.7$ & $62.9 \pm 6.2$ \\
& 200 & $82.0 \pm 0.9$ & $51.2 \pm 0.1$ \\
Sewage & 500 & $70.7 \pm 5.9$ & $50.9 \pm 4.7$ \\
& 1000 & $47.4 \pm 0.0$ & - \\
\hline & 0.5 & $62.3 \pm 7.5^{\mathrm{a}}$ & $37.5 \pm 3.4^{\mathrm{a}}$ \\
& 0.5 & $89.4 \pm 0.5$ & $82.7 \pm 3.4$ \\
\hline
\end{tabular}

$\begin{array}{llll}\text { Anode slime } & 1.2^{\mathrm{b}} & - & 74.8 \pm 5.7\end{array}$

${ }^{a}$ mass of biomass $0.013 \mathrm{~g},{ }^{\mathrm{b}}$ constituent content of anode slime: $\mathrm{Pt}-6 \mu \mathrm{g} \mathrm{g}-1, \mathrm{Ag}-40 \%, \mathrm{~Pb}-30 \%, \mathrm{Sb}-1 \%-3 \%$, $\mathrm{Se}-1 \%-2 \%, \mathrm{Cu}-1 \%-2 \%, \mathrm{~S}-6 \%, \mathrm{Au}-200 \mu \mathrm{g} \mathrm{g}^{-1}, \mathrm{Pd}-7 \mu \mathrm{g} \mathrm{g}^{-1}$. 
Table 4. Application of fungi Aspergillus sp. for separation of $\mathrm{Pd}(\mathrm{II})$ from various samples (sample $\mathrm{pH} 3.5$, mass of biosorbent $0.1 \mathrm{~g}$, contact time $2 \mathrm{~h}$, washing agent: $0.01 \mathrm{~mol} \mathrm{~L}^{-1} \mathrm{HNO}_{3}, \mathrm{n}=3$ ).

\begin{tabular}{|c|c|c|c|}
\hline Sample Type & Metal Amount, $\mu \mathrm{g}$ & Retention $\pm \mathrm{SD}, \%$ & Recovery \pm SD,$\%$ \\
\hline Standard solution & 1000 & $98.1 \pm 0.2$ & $95.2 \pm 3.3$ \\
\hline \multirow{2}{*}{ Road run-off } & 0.5 & $93.7 \pm 0.2$ & $98.8 \pm 3.4$ \\
\hline & 1000 & $99.4 \pm 0.0$ & $82.4 \pm 4.8$ \\
\hline \multirow{3}{*}{ Sewage } & 0.5 & $99.4 \pm 0.3^{\mathrm{a}}$ & $95.8 \pm 5.1^{\mathrm{a}}$ \\
\hline & 0.5 & $91.2 \pm 1.0$ & $86.4 \pm 1.1$ \\
\hline & 1000 & $88.6 \pm 0.9$ & $65.7 \pm 6.2$ \\
\hline Anode slime & $1.4^{\mathrm{b}}$ & - & $97.9 \pm 7.7$ \\
\hline
\end{tabular}

The mean efficiency of retention of $\mathrm{Pt}(500 \mathrm{ng})$ from sewage on $0.013 \mathrm{~g}$ of fungal biomass was about $60 \%$. Therefore, higher biomass dosage $(0.1 \mathrm{~g})$ was used in further experiments. It was observed that the efficiency of biosorption of the same amount of $\mathrm{Pt}$ on higher biosorbent mass from sewage samples increased to $89 \%$ and from run-off samples achieved $95 \%$. The recovery of Pt from digested fungal biomass was lower, in the range of $69 \%-82 \%$, indicating that part of the $\mathrm{Pt}(\mathrm{IV})$ ions was non-specifically bound to the cells' surface. For $20 \mathrm{~mL}$ of standard and samples solutions containing Pt content in the range of $100-500 \mu \mathrm{g}$, the retention efficiency was in the range $95 \%-70 \%$, while the recovery was in the range $70 \%-50 \%$, decreasing with increasing Pt concentration (Table 3). The retention of analyte from samples containing $1000 \mu \mathrm{g}$ of Pt decreased to about $57 \%$ from standard solutions and even below $50 \%$ for complex samples. In this case, the platinum uptake was only about $2.8 \mathrm{mg} \mathrm{g}^{-1}$, not exceeding the maximal capacity of the sorbent. Probably the biosorption of high amounts of $\mathrm{Pt}$ was restricted by some factors. Competition between Pt and other ions, organic matter in sewage and road run-off samples, cannot be neglected.

Under the same conditions the recovery of Pd from biomass for all samples type was quantitative (Table 4). These results proved that Pd was specifically bound to fungal cells and no competition in biosorption was observed.

Owing to the presence of valuable metals and metalloids in the anode slime, products obtained from electrolytic refining of copper, numerous approaches have been made by the researchers to extract them following metallurgical routes [51]. The samples of anode slime were digested and pretreated according to the procedure described in Section 2.6. The content of $\mathrm{Pt}$ in anode slime determined by XRF method was $6 \mu \mathrm{g} \mathrm{g}^{-1}$, while the content of Pd was $7 \mu \mathrm{g} \mathrm{g}^{-1}$.

The experiment has shown that the recovery of precious metals from fungal biomass was excellent for Pd $(97.9 \pm 7.7 \%, n=3)$ and good for Pt $(74.8 \pm 5.7 \%, n=3)$. In this work, the biomass was digested by means of high temperature in concentrated acid. The obtained results show that the biomass of fungi can be applied for the quantitative recovery of palladium from wastewater and industrial samples. As for the recovery of precious metals from biomass an incineration process could be used [24], we also plan to examine the efficiency of this process in the future.

\section{Conclusions}

Yeast Saccharomyces sp. and fungi Aspergillus sp. have been used to investigate the biosorption of trace amounts of $\mathrm{Pt}(\mathrm{IV})$ and $\mathrm{Pd}(\mathrm{II})$ from chloride solutions in a batch system. The maximal efficiency of retention of $\mathrm{Pt}(\mathrm{IV})$ on yeast and fungi was obtained at $\mathrm{pH} 2.0 \pm 0.2$. The biosorption of $\mathrm{Pd}(\mathrm{II})$ was performed at $\mathrm{pH} 2.5 \pm 0.2$ on yeast, and $\mathrm{pH} 3.5 \pm 0.2$ on fungi. The biosorption process is very fast as the equilibrium was attained within $45 \mathrm{~min}$. The best interpretation for the experimental data was given by the Langmuir isotherm and pseudo-second-order kinetics model. Fungi Aspergillus sp. show a higher adsorption capacity for both metals than yeast Saccharomyces sp. The maximum adsorption capacity of fungi was $5.49 \mathrm{mg} \mathrm{g}^{-1}$ for $\mathrm{Pt}(\mathrm{IV})$ and $4.28 \mathrm{mg} \mathrm{g}^{-1}$ for $\mathrm{Pd}(\mathrm{II})$. This microorganism was used for efficient removal of $\mathrm{Pt}$ and $\mathrm{Pd}$ from environmental samples (sewage, road run-off). The method 
could be also applied for the recovery of Pd from industrial samples (anode slime). The results revealed that, although this new biosorbent has a relatively low capacity, it is a promising candidate for removal of palladium from contaminated aquatic environments and industrial wastes. If the amount and value of metal recovered and if the biomass is plentiful, metal loaded biomass can be incinerated thereby eliminating further treatment.

Author Contributions: B.G.-Ż. conceptualization, writing, supervision, S.S. investigation, data calculation and preparation of figures, J.K. calculation of kinetics parameters.

Funding: This research received no external funding.

Conflicts of Interest: The authors declare no conflict of interest.

\section{References}

1. Bossi, T. Environmental Profile of Platinum Group Metals Interpretation of the results of a cradle-to-gate life cycle assessment of the production of pgms and the benefits of their use in a selected application. Johns. Matthey Technol. Rev. 2017, 61, 111-121. [CrossRef]

2. Cui, J.; Zhang, L. Metallurgical recovery of metals from electronic waste: A review. J. Hazard. Mater. 2008, 158, 228-256. [CrossRef] [PubMed]

3. Matthey, J. Precious Metal Division, Johnson Matthey Publishing Company. Available online: http://www.platinum. matthey.com/documents/new-item/pgm\%20market\%20reports/pgm-market-report-may-2016.pdf (accessed on 10 May 2019).

4. Zereini, F.; Alt, F. Anthropogenic Platinum Group Element Emission; Springer: Berlin, Germany, 2000.

5. Zereini, F.; Alt, F. Palladium Emissions in the Environment, Analytical Methods, Enviromental Assessment and Health Effects; Springer: Berlin, Germany, 2006.

6. Kalavrouziotis, I.K.; Koukoulakis, P.H. The environmental impact of the platinum group elements $(\mathrm{Pt}, \mathrm{Pd}$, Rh) emitted by the automobile catalyst converters. Water Air Soil Pollut. 2009, 196, 393-402. [CrossRef]

7. Jackson, M.T.; Richard, H.M.; Samson, J. Platinum-group elements in sewage sludge and incinerator ash in the United Kingdom: Assessment of PGE sources and mobility in cities. Sci. Total Environ. 2010, 408, 1276-1285. [CrossRef] [PubMed]

8. Rauch, S.; Morrison, G.M.; Motelica-Heino, M.; Donard, O.F.X.; Muris, M. Elemental association and fingerprints of traffic-related metals in road sediments. Environ. Sci. Technol. 2000, 33, 3119-3123. [CrossRef]

9. Nuss, P.; Blengini, G.A. Towards better monitoring of technology critical elements in Europe: Coupling of natural and anthropogenic cycles. Sci. Total Environ. 2018, 613, 569-578. [CrossRef] [PubMed]

10. Alhuwalia, S.S.; Goyal, D. Microbial and plant derived biomass for removal of heavy metals from wastewater. Bioresour. Technol. 2007, 98, 2243-2257. [CrossRef] [PubMed]

11. Park, D.; Yun, Y.S.; Park, J.M. The past, present and future trends of biosorption. Biotechnol. Bioprocess Eng. 2010, 15, 86-102. [CrossRef]

12. Das, N. Recovery of precious metals through biosorption-A review. Hydrometallurgy 2010, 103, 180-189. [CrossRef]

13. Lim, J.S.; Kim, S.M.; Lee, S.Y.; Stach, E.A.; Culver, J.N.; Harris, M.T. Quantitative study of Au(III) and Pd(II) ion biosorption on genetically engineered Tobacco mosaic virus. J. Colloid Interface Sci. 2010, 342, 455-461. [CrossRef]

14. Park, J.; Won, S.W.; Mao, J.; Kwak, I.S.; Yun, Y.S. Recovery of Pd(II) from hydrochloric solution using polyallylamine hydrochloride-modified Escherichia coli biomass. J. Hazard. Mater. 2010, 181, 794-800. [CrossRef] [PubMed]

15. Escudero, L.B.; Maniero, M.A.; Agostini, E.; Smichowski, P.N. Biological substrates: Green alternatives in trace elemental preconcentration and speciation analysis. Trends Anal. Chem. 2016, 80, 531-546. [CrossRef]

16. Chassary, P.; Vincent, T.; Marcano, J.S.; Macaskie, L.E.; Guibal, E. Palladium and platinum recovery from bicomponent mixtures using chitosan derivatives. Hydrometallurgy 2005, 76, 131-147. [CrossRef]

17. Ramesh, A.; Hasegawa, H.; Sugimoto, W.; Maki, T.; Ueda, K. Adsorption of gold(III), platinum(IV) and palladium(II) onto glycine modified crosslinked chitosan resin. Bioresour. Technol. 2008, 99, 3801-3809. [CrossRef] [PubMed] 
18. Zhou, L.; Xu, J.; Liang, X.; Liu, Z. Adsorption of platinum(IV) and palladium(II) from aqueous solution by magnetic cross-linking chitosan nanoparticles modified with ethylenediamine. J. Hazard. Mater. 2010, 182, 518-524. [CrossRef] [PubMed]

19. Kim, Y.H.; Nakano, Y. Adsorption mechanism of palladium by redox within condensed-tannin gel. Water Res. 2005, 39, 1324-1330. [CrossRef] [PubMed]

20. Wang, R.; Liao, X.; Shi, B. Adsorption behaviors of $\mathrm{Pt}(\mathrm{II})$ and $\mathrm{Pd}(\mathrm{II})$ on collagen fibre immobilized bayberry tannin. Ind. Eng. Chem. Res. 2005, 44, 4221-4226. [CrossRef]

21. Sari, A.; Durali, M.; Tuzen, M.; Soylak, M. Biosorption of palladium(II) from aqueous solution by moss (Racomitrium lanuginosum) biomass: Equilibrium, kinetic and thermodynamic studies. J. Hazard. Mater. 2009, 162, 874-879. [CrossRef]

22. Parajuli, D.; Hirota, K. Recovery of palladium using chemically modified cedar wood powder. J. Colloid Interface Sci. 2009, 338, 371-375. [CrossRef]

23. Won, S.W.; Mao, J.; Kwak, I.S.; Sathishkumar, M.; Yun, Y. Platinum recovery from ICP wastewater by a combined method of biosorption and incineration. Bioresour. Technol. 2010, 101, 1135-1140. [CrossRef]

24. Won, S.W.; Lim, A.; Yun, Y.S. Recovery of high purity metallic Pd from Pd(II)-sorbed biosorbents by incineration. Bioresour. Technol. 2013, 137, 400-403. [CrossRef] [PubMed]

25. de Vargas, I.; Macaskie, L.E.; Guibal, E. Biosorption of palladium and platinum by sulfate-reducing bacteria. J. Chem. Technol. Biotechnol. 2004, 79, 49-56. [CrossRef]

26. Kim, S.; Song, M.H.; Wei, W.; Yun, Y.S. Selective biosorption behavior of Escherichia coli biomass toward Pd(II) in Pt(IV)-Pd(II) binary solution. J. Hazard. Mater. 2015, 283, 657-662. [CrossRef] [PubMed]

27. Xu, H.; Tan, L.; Dong, H.; He, J.; Liu, X.; Qiu, G.; He, Q.; Xie, J. Competitive biosorption behavior of Pt(IV) and Pd(II) by Providencia vermicola. RSC Adv. 2017, 7, 32229-32235. [CrossRef]

28. Turner, A.; Lewis, M.S.; Shams, L.; Brown, M.T. Uptake of platinum group elements by marine macroalga. Mar. Chem. 2007, 105, 271-280. [CrossRef]

29. Dziwulska, U.; Bajguz, A.; Godlewska-Żyłkiewicz, B. The use of algae Chlorella vulgaris immobilized on Cellex-T support for separation/preconcentration of trace amounts of platinum and palladium before GFAAS determination. Anal. Lett. 2004, 37, 2189-2203. [CrossRef]

30. Ju, X.; Igarashi, K.; Miyashita, S.I.; Mitsuhashi, H.; Inagaki, K.; Fujii, S.I.; Sawada, H.; Kuwabara, T.; Minoda, A. Effective and selective recovery of gold and palladium ions from metal wastewater using a sulfothermophilic red alga. Galdieria sulphuraria. Bioresour. Technol. 2016, 211, 759-764. [CrossRef] [PubMed]

31. Blackwell, K.J.; Singleton, I.; Tobin, J.M. Metal cation uptake by yeast: A review. Appl. Microbiol. Biotechnol. 1995, 43, 579-584. [CrossRef] [PubMed]

32. Mack, C.L.; Wilhelmi, B.; Duncan, J.R.; Burgess, J.E. A kinetic study of the recovery of platinum ions from an artificial solution by immobilized Saccharomyces cerevisiae biomass. Miner. Eng. 2008, 21, 31-37. [CrossRef]

33. Godlewska-Żyłkiewicz, B. Biosorption of platinum and palladium for their separation/ pre-concentration prior to graphite furnace atomic absorption spectrometric determination. Spectrochim. Acta Part B 2003, 58, 1531-1540. [CrossRef]

34. Godlewska-Żyłkiewicz, B.; Kozłowska, M. Solid phase extraction using immobilized yeast Saccharomyces cerevisiae for determination of palladium in road dust. Anal. Chim. Acta 2005, 539, 61-67. [CrossRef]

35. Malejko, J.; Szygałowicz, M.; Godlewska-Żyłkiewicz, B.; Kojło, A. Sorption of platinum on immobilized microorganisms for its on-line preconcentration and chemiluminescent determination in water samples. Microchim Acta 2012, 176, 429-435. [CrossRef] [PubMed]

36. Magnuson, J.; Lasure, L. Organic acid production by filamentous fungi. In Advances in Fungal Biotechnology for Industry, Agriculture, and Medicine; Tkacz, J., Lange, L., Eds.; Kluwer Academic \& Plenum Publishers: New York, NY, USA, 2004; pp. 307-340.

37. Kapoor, A.; Viraraghavan, T. Heavy metal biosorption sites in Aspergillus niger. Bioresour. Technol. 1997, 61, 221-227. [CrossRef]

38. Akar, T.; Tunali, S. Biosorption characteristics of Aspergillus flavus biomass for removal of $\mathrm{Pb}$ (II) and Cu(II) ions from and aqueous solution. Bioresour. Technol. 2006, 97, 1780-1787. [CrossRef] [PubMed]

39. Baytak, S.; Kocyigit, A.; Turker, A.R. Determination of lead, iron and nickel in water and vegetable samples after preconcentration with Aspergillus niger loaded on silica gel. Clean 2007, 35, 607-611.

40. Moore, B.A.; Duncan, J.R.; Burgess, J.E. Fungal bioaccumulation of copper, nickel, gold and platinum. Miner. Eng. 2008, 21, 55-60. [CrossRef] 
41. Woińska, S.; Godlewska-Żyłkiewicz, B. Determination of platinum and palladium in road dust after their separation on immobilized fungus by electrothemal atomic absorption spectrometry. Spectrochim. Acta Part B 2011, 66, 522-528. [CrossRef]

42. Sadowski, Z.; Maliszewska, I.H.; Grochowalska, B.; Polowczyk, I.; Koźlecki, T. Synthesis of silver nanoparticles using microorganisms. Mater. Sci. Pol. 2008, 26, 419-424.

43. Volesky, B. Sorption and Biosorption; Bv Sorbex: Montreal, QC, Canada, 2003; pp. 103-116.

44. Freundlich, H. Ueber die Adsorption in Loesungen. Z. Physik. Chem. 1907, 57, 385-470.

45. Langmuir, I. The adsorption of gases on plane surfaces of glass, mica and platinum. J. Am. Chem. Soc. 1918, 40, 1361-1403. [CrossRef]

46. Spieker, W.A.; Liu, J.; Miller, J.T.; Kropf, A.J.; Regalbuto, J.R. An EXAFS study of the co-ordination chemistry of hydrogen hexachloroplatinate(IV) 1. Speciation in aqueous solution. Appl. Catal. A Gen. 2002, 232, 219-235. [CrossRef]

47. Cabuk, A.; Akar, T.; Tunali, S.; Gedikli, S. Biosorption of $\mathrm{Pb}(\mathrm{II})$ by industrial strain of Saccharomyces cerevisiae immobilized on the biomatrix of cone biomass of Pinus nigra: Equilibrium and mechanism analysis. Chem. Eng. J. 2007, 131, 293-300. [CrossRef]

48. Sarri, S.; Misaelides, P.; Papanikolaou, M.; Zambulis, D. Uranium removal from acidic aqueous solutions by Saccharomyces cerevisiae, Debaruomyces hansenii, Kluyveromyces marxianus and Candida colliculosa. J. Radioanal. Nucl. Chem. 2009, 279, 709-711. [CrossRef]

49. Chen, C.; Wang, J. Influence of metal ionic characteristic on their biosorption capacity by Saccharomyces cerevisiae. Appl. Microbiol. Biotechnol. 2007, 74, 911-917. [CrossRef] [PubMed]

50. Netzahuatl-Muñoz, A.R.; del Carmen Cristiani-Urbina, M.; Cristiani-Urbina, E. Chromium biosorption from $\mathrm{Cr}(\mathrm{VI})$ aqueous solutions by Cupressus lusitanica bark: Kinetics, equilibrium an thermodynamic studies. PLoS ONE 2015, 10, e0137086. [CrossRef] [PubMed]

51. Hait, J.; Jana, R.K.; Sanyal, S.K. Processing of copper electrorefining anode slime: A review. Miner. Process. Extr. Metall. 2009, 118, 240-252. [CrossRef]

(C) 2019 by the authors. Licensee MDPI, Basel, Switzerland. This article is an open access article distributed under the terms and conditions of the Creative Commons Attribution (CC BY) license (http://creativecommons.org/licenses/by/4.0/). 